\title{
Surface Water Quality Trends and Regression Model through SPSS in Udaipur, Rajasthan
}

\author{
Sangeeta Choudhary ${ }^{1}$, Jahnvi Sharma ${ }^{2}$ \\ ${ }^{1}$ Associate Professor - Civil Engineering, Geetanjali Institute of Technical Studies \\ ${ }^{2} \mathrm{UG}$-Civil Engineering, Geetanjali Institute of Technical Studies, Udaipur (Rajasthan)
}

\begin{abstract}
Surface water quality status and trend of Udaipur's main lakes namely, Fatehsagar, Pichola lake and Udaisagar has been identify through 10 years freely available online data collected from ENVIS Centre under on Control of Pollution of Water, Air and Noise. Water quality data was collected for the parameters like BOD, DO, pH, Conductivity, NN, Fecal coliform, Total coliform to determine the water pollution level and water treatment requirements. Overall water quality status has been improved during 2016 to 2019 due to waste water treatment plant. Udaisagar is most polluted lake among three lakes. Fecal coliform was suddenly increased in 2018 due to leakage of sewage line near the Pichola Lake. These lakes are interconnected and very useful for drinking, industrial, agricultural and tourism purpose and proper maintenance will be helpful for all dimensional growth of the city. A regression model for BOD was also developed for these lakes. Dependency of Temperature, pH, Dissolved oxygen, NN, Fecal coliform and Total coliform were checked on BOD through SPSS multiple regression analysis. It is found that only Temperature and Total Coliform affects the values of BOD. The variance analysis showed p-values is less than 0.05 and no multicollinearity was diagnosed, with VIF values of $<10$.
\end{abstract}

Keywords: Surface Water, Regression, Water Quality, BOD, Total Coliform, Temperature.

\section{INTRODUCTION}

The study area Udaipur district in Rajasthan is located between $23^{\circ} 46^{\prime} \& 25^{\circ} 05^{\prime}$ North latitude and $73^{\circ} 09^{\prime}$ \& $74^{\circ} 35^{\prime}$ East longitude covering an area of 13419 sq. km. Udaipur gets an annual rainfall $640 \mathrm{~mm}$. Established some 425 years ago Udaipur's system of lakes was considered a role model of rainwater management [1]. Pichola lake, Fatehsagar, Doodh Talai, Goverdhan Sagar, Badi, Rangsagar, Swaroop Sagar and Udaisagar are major lakes in Udaipur [2]. It is the good model of rainwater harvesting of all the lakes in Udaipur. Lakes are interconnected, overflow from one goes to the next and they are the major source of drinking water of the city [3]. The aim of this study is to determine the status and trend of surface water quality in previous 10 years of Pichola lake, Udaisagar lake, Fateh Sagar lake for multi-criteria decision like for provisioning of safe drinking water for increasing population, development of industries, tourism and agriculture activities in Udaipur as Smart city [4][5][6]. Idea of the Smart Cities Mission is to make economic growth and get better the quality of life of citizens by enabling local area development. Four cities of Rajasthan namely Jaipur, Udaipur, Kota and Ajmer from Rajasthan have been selected by Indian Government under Smart City Mission. The tourism industry has got a big boost as Udaipur has been included in the list of most beautiful cities of the globe. Surface water quality plays an important role for overall development of the city [7][8]. There are 8 quality parameters in this study temperature, dissolved oxygen, $\mathrm{pH}$, conductivity, BOD, Nitrate Nitrite, fecal coliform and total coliform [9] [10] [11]. A regression model for Biochemical Oxygen Demand (BOD) is developed for surface water of Pichola Lake, Fatehsagar Lake and Udaisagar of Udaipur [12]. BOD is the rate of oxygen utilization in a watercourse. It is affected by a number of variables like temperature, $\mathrm{pH}$, the existence of microorganisms and type of organic and inorganic matter in water.

\section{METHODOLOGY}

The main objective of this study to identify the trend and status of surface water quality of Udaipur city for making multi criteria decision policy for development of the city. Major three lakes Pichola, Udaisagar and Fatehsagar have been included for comparative study. These lakes are the important and interconnected that provides portable water to around 5 million citizens. These also supply water to industrial complexes [13][14]. There were 10 years (2010-2019) data of eight parameters i.e. Temperature, $\mathrm{pH}$, Conductivity, Dissolved Oxygen (DO), Nitrate-Nitrite (NN), Biochemical Oxygen Demand (BOD), Fecal Coliform and Total Coliform were included for comparative study of three lakes [15]. Data were collected from ENVIS Centre on Control of Pollution Water, Air and Noise, hosted by Central Pollution Control Board. A multiple linear regression analysis is carried out to predict the values of a dependent variable BOD. A regression model for BOD was also developed through SPSS multi regression method. The 


\section{DOI: $10.17148 /$ IARJSET.2021.81030}

correlation between independent and dependent variables can be determined through multiple regression analysis. It fits a best line and predicts the impact of two or more independent variables on a dependent variable [16]. The regression model is considered significant and appropriate when p-value is smaller than 0.05. BOD of water gives health of water body and is required to be check by keeping the factors affecting BOD. The analysis through regression method, mentioning in the paper is to find the major factors which affects the BOD most.

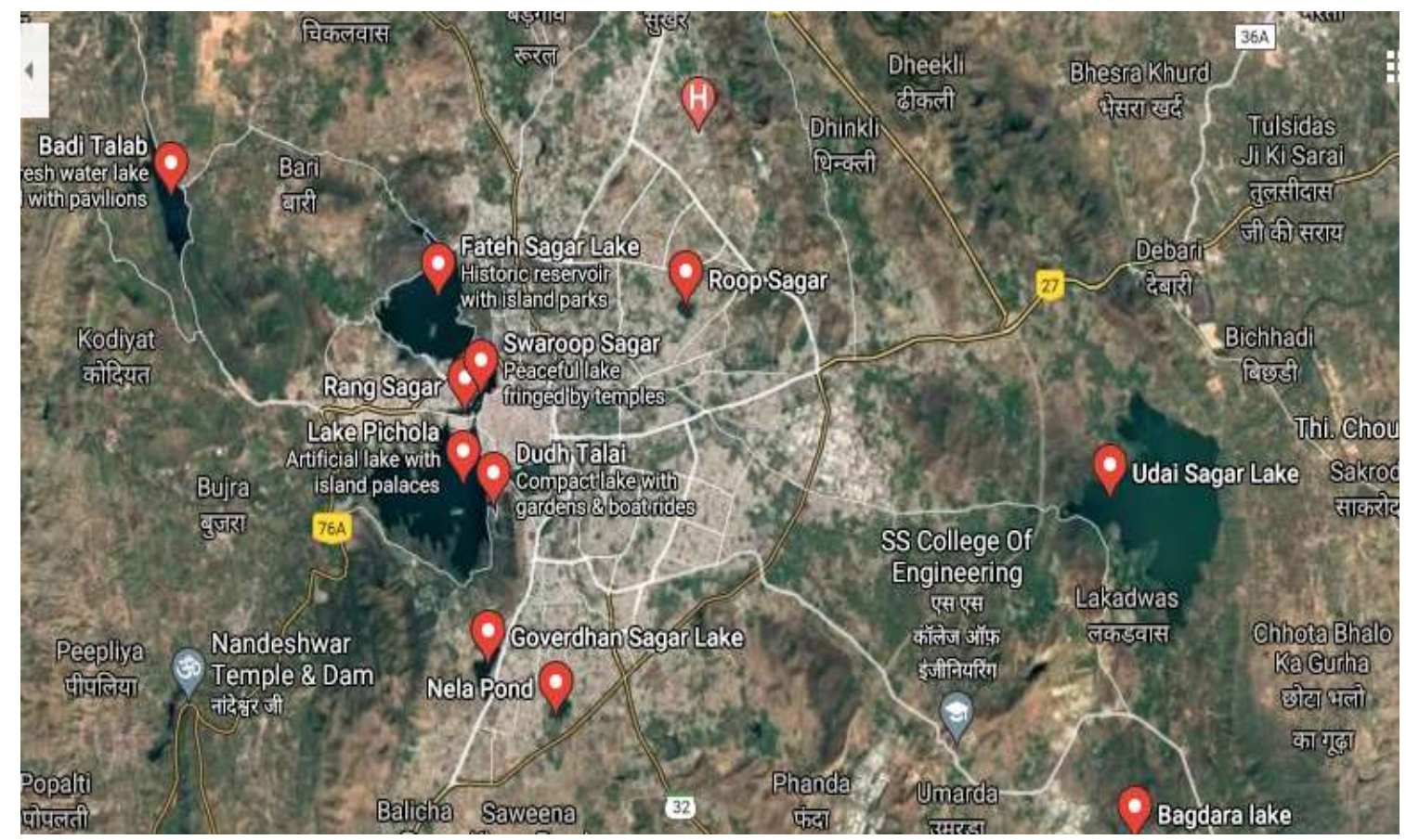

Fig 1. Locations of Fatehsagar, Pichola Lake and Udaisagar (Google Map)

\section{RESULT AND DISCUSSIONS}

Comparative graphs from 1 to 8 of Pichola, Udaisagar and Fatehsagar Lakes show the status and trends of last 10 years (2010-19). The BOD is a reliable gauge of the organic pollution of a water body [17]. The decay of organic matter in water is measured as BOD. Last 10 years result shows that BOD values of Udaisagar are very high except 2016 and 2018. Industrial and domestic sewage through Ayar River, are main cause of high value of BOD in Udaisagar. DO level of these lakes has been increasing after 2014.

It should be above $4 \mathrm{ppm}$ for comfortable aquatic life. Low value of Dissolved oxygen indicates higher oxygen is consumed as microorganisms use it in their metabolism. BOD is inversely proportional to DO in water. Dissolved oxygen in Udaisagar is very low due to disposal of industrial and domestic sewage before 2014. Injurious effects become visible when the $\mathrm{pH}$ of water falls below 5.0 or rise above 9.6. $\mathrm{pH}$ value of all lakes are in tolerable range. Mineral composition of the surrounding soil, dissolved salts and carbonates affects the alkalinity of water increases with the higher values of the alkalinity [18] [19]. Higher conductivity value of Udaisagar Lake indicates that there are more chemicals dissolved in the water. Higher amounts of these impurities will lead to a higher conductivity. Measurement of electrical conductivity of water is a very useful for environmental and industrial applications [20][21].

According to WHO Guidelines for Drinking-water Quality the nitrate concentration in surface water is normally low $(0-18 \mathrm{mg} / \mathrm{l})$ but can reach high levels as a result of agricultural runoff, refuse dump runoff or contamination with human or animal wastes [22]. Nitrite levels in drinking-water are usually below $0.1 \mathrm{mg} / \mathrm{l}$. Nitrate and Nitrite level of theses lakes are in permissible limit. Total coliform include bacteria that are found in the soil and in human and animal waste. Fecal coliforms are the group of the total coliforms that are considered to be present specifically in the gut and feces of warm-blooded animals [23][ 24]. Total coliform and fecal coliform are also high in Udai Sagar Lake except few year like fecal coliform of Pichola was highest in 2018 due to leakage of sewage line near this lake and Total coliform was highest in 2011. It was concluded on the basis of last 10 years data that water quality of Udai Sagar lake is poor than Fateh sagar and Pichola lake. Dissolved oxygen is less whereas values of BOD, pH, Fecal and Total 


\section{International Advanced Research Journal in Science, Engineering and Technology}

Vol. 8, Issue 10, October 2021

DOI: 10.17148/IARJSET.2021.81030

coliform are high in Udai sgar lake in comparision to Fateh Sagar and Pichola Lake. There are two following main reasons of high pollution of Udai Sagar:

- $\quad$ Ayar river brings household and industrial waste into the Udaisagar lake as it passes through Udaipur city.

- Hindustan Zinc Limited situated in the surrounding area of Udaisagar, extracts the lake water and releases its untreated effluent into it.

There are some improvements in water quality during 2016 to 2018 due to a agreement between the Hindustan Zinc and the local government was formed in May 2012 to develop the city`s first Wastewater Treatment Plant (WWTP) which addressed both stakeholders objectives. Commissioned in April 2014, the plant has a treatment capacity which equates to $30 \%$ of Udaipur's daily wastewater. Human health can be impacted directly or indirectly through coliform bacteria present in water bodies. So proper water management has been required. [25][26]. Table 1 indicates the surface area of Udaisagar is highest among these three lakes and pollution level prevents the growth of the city. More treatment processes in Udaisagar lake can increase the use of water for domestic, industrial and agricultural fields. Tourism sector can be improved near the lake like Fatehsagar and Pichola Lake. It will be helpful for the economic growth of the city.

\section{Biochemical Oxygen Demand}

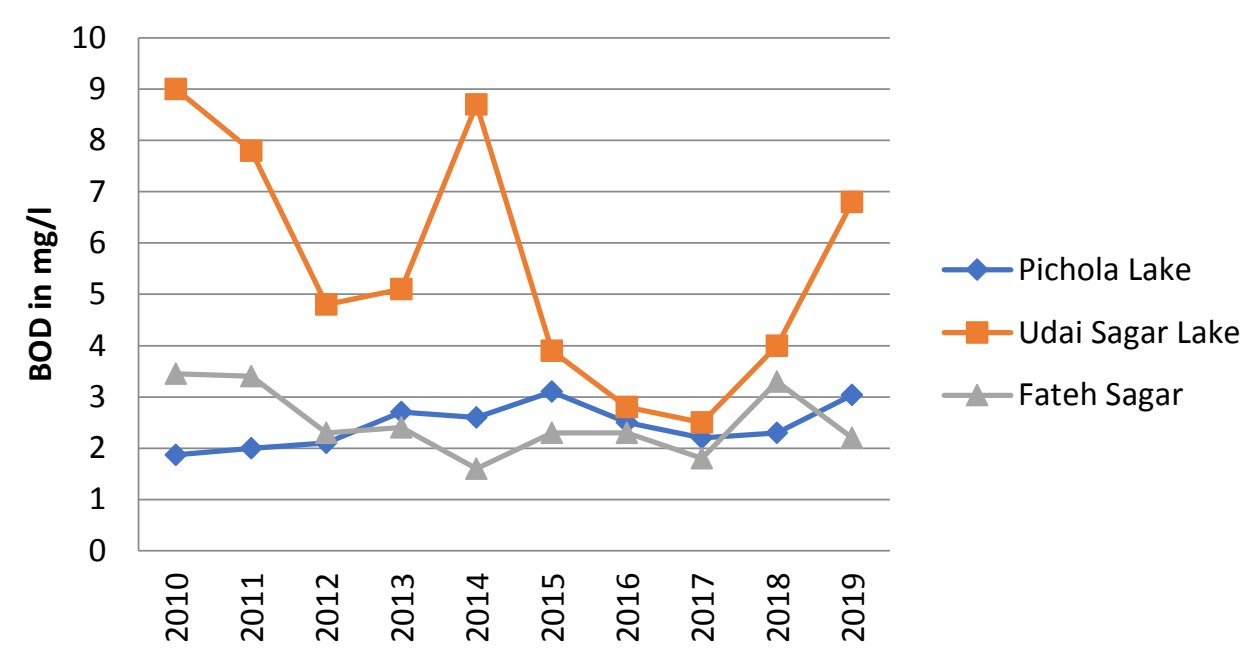

Graph 1: Biochemical Oxygen Demand in mg/l from 2010 to 2019

\section{Dissolved Oxygen}



Graph 2: Dissolved Oxygen in mg/l from 2010 to 2019 
International Advanced Research Journal in Science, Engineering and Technology

Vol. 8, Issue 10, October 2021

DOI: $10.17148 /$ IARJSET.2021.81030

\section{pH Values}

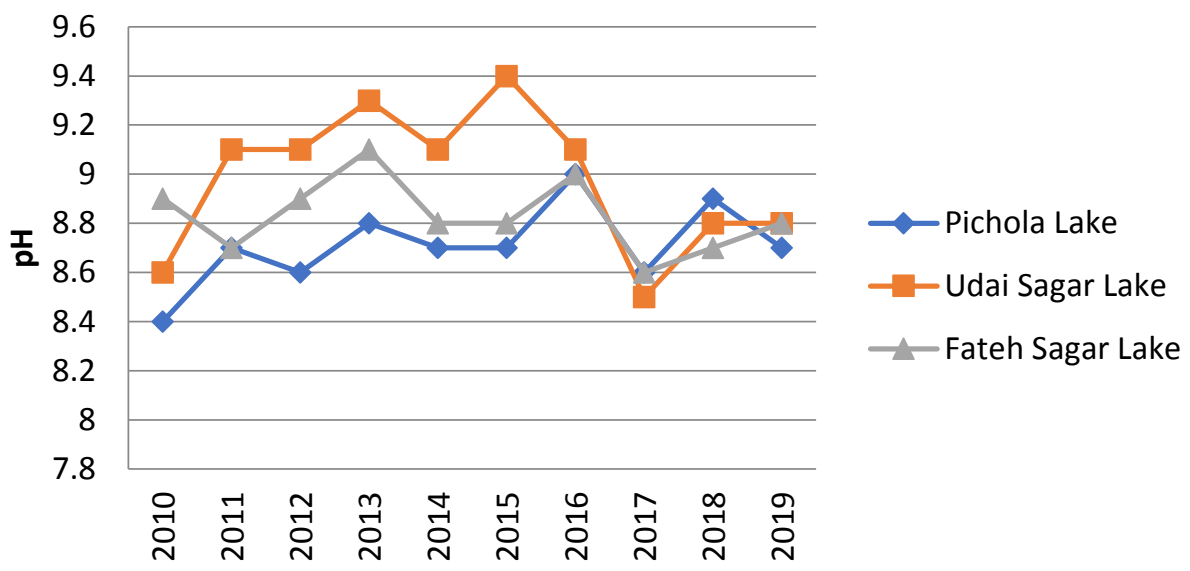

Graph 3: pH values from 2010 to 2019

\section{Conductivity Values}

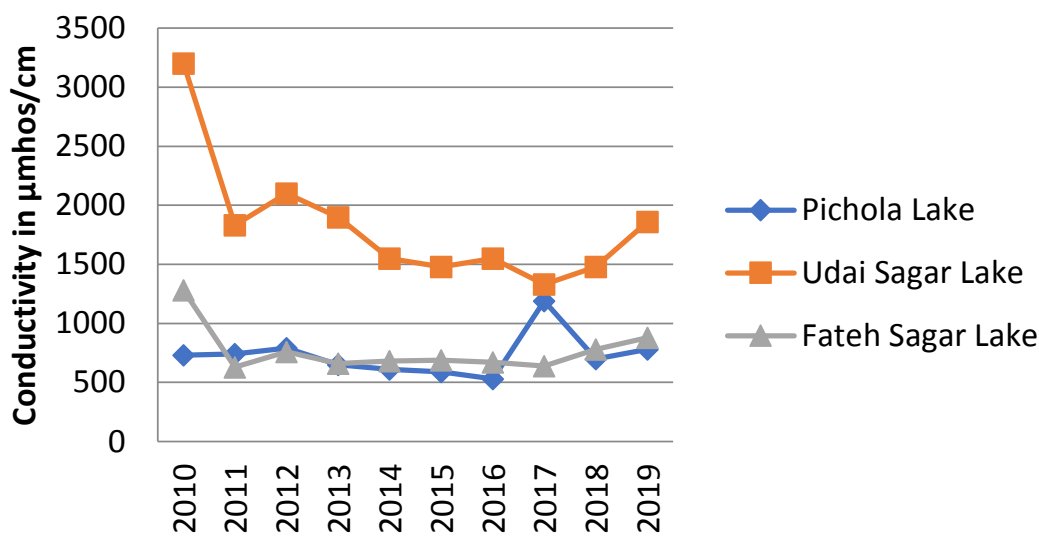

Graph 4: Conductivity in $\mu \mathrm{mhos} / \mathrm{cm}$

Nitrate + Nitrite

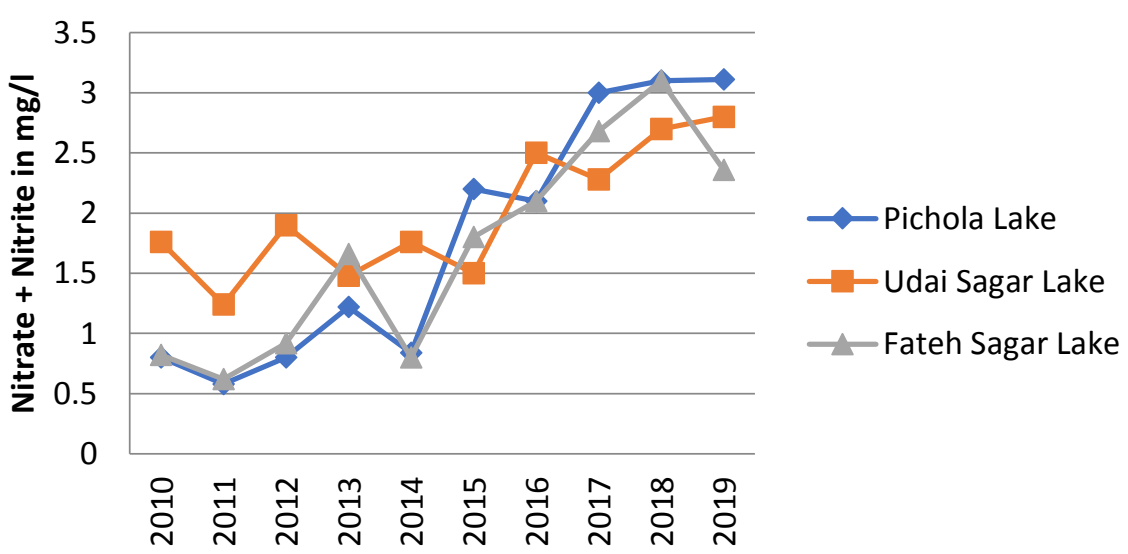

Graph 5: Nitrate N + Nitrogen N in mg/l from 2010 to 2019 
International Advanced Research Journal in Science, Engineering and Technology

Vol. 8, Issue 10, October 2021

DOI: $10.17148 /$ IARJSET.2021.81030

\section{Total Coliform}

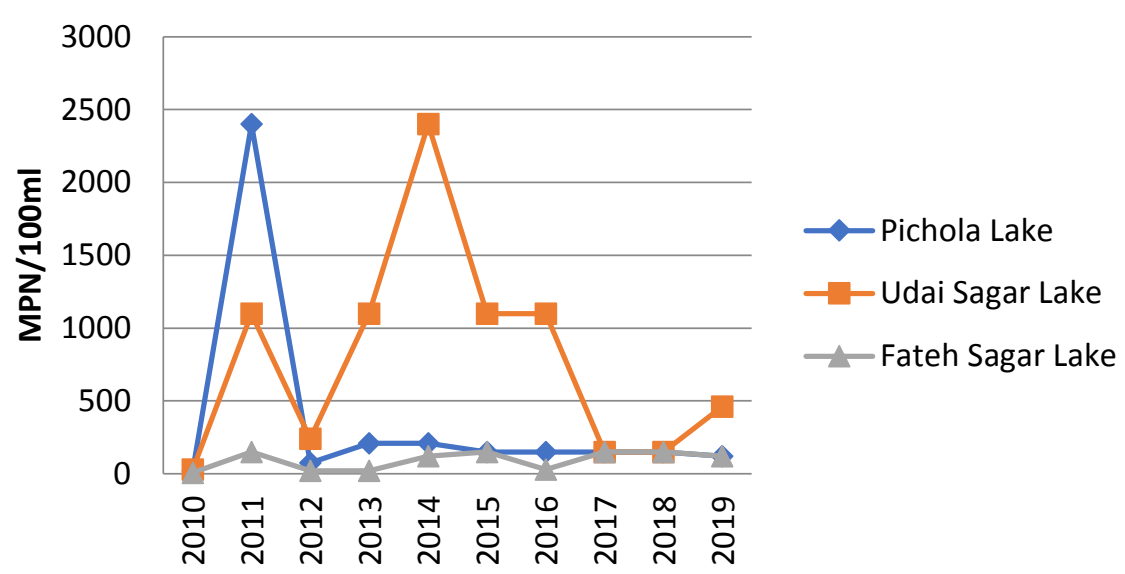

Graph 6: Total Coliform in MPN/100ml from 2010 to 2019

\section{Fecal Coliform}

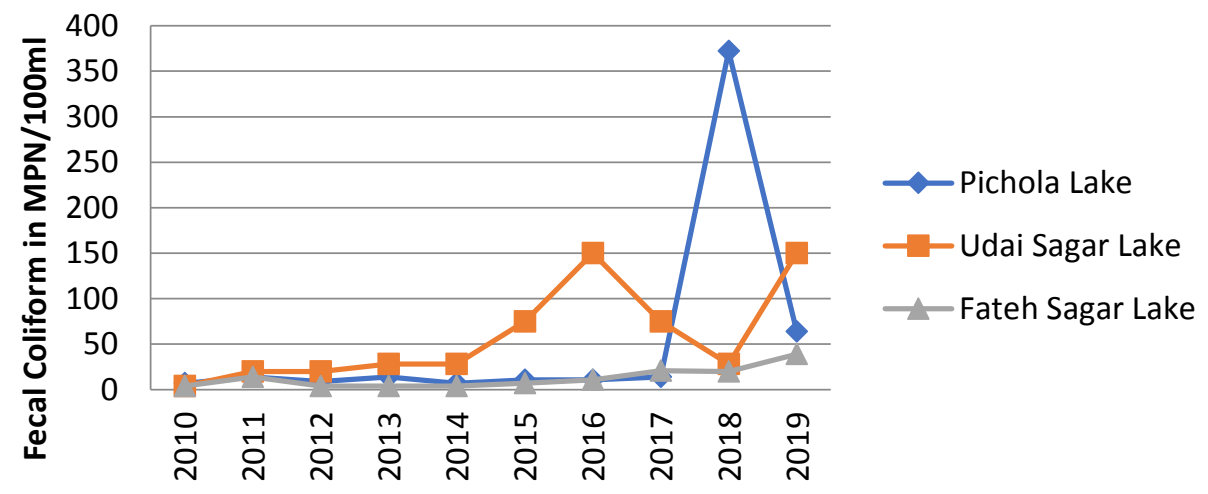

Graph 7: Fecal Coliform in MPN/100 ml from 2010 to 2019

\section{Temperature}

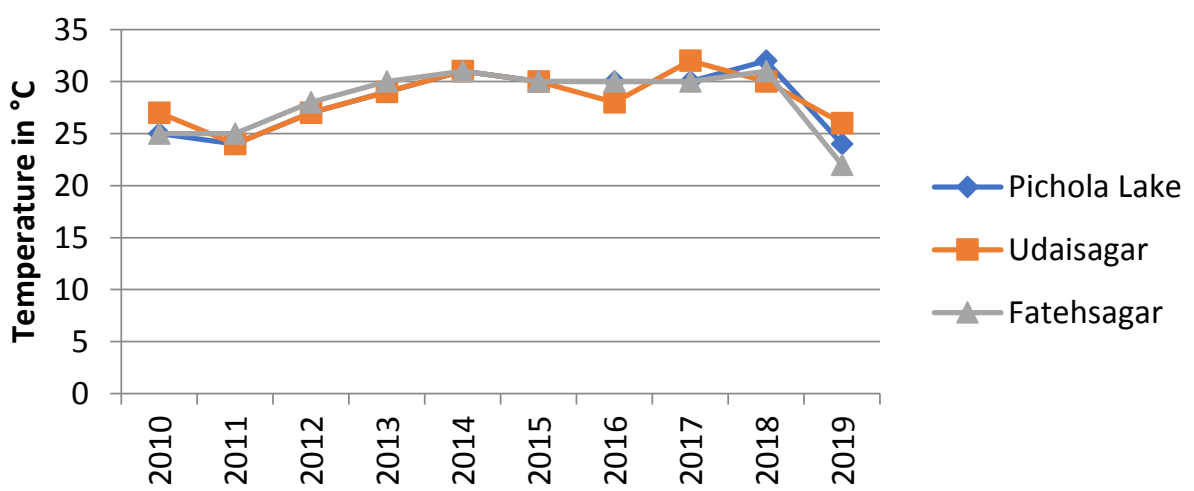

Graph 8: Temperature in ${ }^{0} \mathrm{C}$ from 2010 to 2019 
International Advanced Research Journal in Science, Engineering and Technology

Vol. 8, Issue 10, October 2021

DOI: 10.17148/IARJSET.2021.81030

Table 1. Dimensions of Major Lakes in Udaipur

\begin{tabular}{|l|l|l|l|}
\hline Dimensions of Lakes & Udaisagar Lake & Pichola Lake & Fatehsagar Lake \\
\hline Max Length $(\mathrm{km})$ & 4 & 4 & 2.4 \\
\hline Max Width $(\mathrm{km})$ & 2.5 & 3 & 1.6 \\
\hline Surface Area $\left(\mathrm{km}^{2}\right)$ & 10.5 & 6.96 & 4 \\
\hline Max depth $(\mathrm{m})$ & 9 & 8.5 & 13.4 \\
\hline
\end{tabular}

Regression Analysis Results: Table 2 and 3 shows the correlation and regression results. The assumption of this study was that all three lakes were considered as one surface unit for mathematical model. Different multiple regression analysis has been done through SPSS and one dependent variable BOD were identified.

Table 2. Correlation

\begin{tabular}{|l|l|l|l|l|}
\hline & & BOD & Temperature & Total_Coliform \\
\hline \multirow{4}{*}{ Pearson Correlation } & BOD & 1.000 & .525 & .524 \\
\cline { 2 - 5 } & Temperature & .525 & 1.000 & .320 \\
\cline { 2 - 5 } & Total Coliform & .524 & .320 & 1.000 \\
\hline \multirow{5}{*}{ Sig. (1- tailed) } & BOD &. & .000 & .000 \\
\cline { 2 - 5 } & Temperature & .000 &. & .006 \\
\cline { 2 - 5 } & Total Coliform & .000 & .006 &. \\
\hline \multirow{3}{*}{$\mathrm{N}$} & BOD & 60 & 60 & 60 \\
\cline { 2 - 5 } & Temperature & 60 & 60 & 60 \\
\cline { 2 - 5 } & Total Coliform & 60 & 60 & 60 \\
\hline
\end{tabular}

Table 3. Regression Result

\begin{tabular}{|c|c|c|c|c|c|c|c|}
\hline & \multicolumn{2}{|c|}{$\begin{array}{l}\text { Unstandardized } \\
\text { Coefficients }\end{array}$} & \multirow{2}{*}{$\begin{array}{l}\text { Standardized } \\
\text { Coefficients } \\
\text { Beta }\end{array}$} & \multirow[t]{2}{*}{$\mathrm{t}$} & \multirow[t]{2}{*}{ Sig. } & \multicolumn{2}{|c|}{$95 \%$ confidence Interval for $B$} \\
\hline & $\mathrm{B}$ & Std. Error & & & & $\begin{array}{l}\text { Lower } \\
\text { Bound }\end{array}$ & Upper Bound \\
\hline Constant & -0.649 & 0.699 & & -0.929 & 0.357 & -2.050 & 0.751 \\
\hline Temperature & 0.115 & 0.031 & 0.398 & 3.725 & 0.000 & 0.053 & 0.177 \\
\hline Total Coliform & 0.002 & 0.000 & 0.397 & 3.713 & 0.000 & 0.001 & 0.002 \\
\hline
\end{tabular}

\section{*Dependent Variable: BOD}

Following model were developed for surface water of Udaipur. Biochemical oxygen demand depends on temperature and total coliform in water.

BOD $=0.115$ Temperature $+\mathbf{0 . 0 0 2}$ Total Coliform $-\mathbf{0 . 6 4 9}$

\section{Validity of Regression Analysis:}

Dependency of Temperature, pH, Dissolved oxygen, NN, Feacal coliform and Total coliform were checked on BOD through SPSS multiple regression analysis. Only Temperature and Total Coliform affects the values of BOD. The variance analysis showed p-values are less than 0.05 and no multicollinearity was diagnosed, with VIF values are less than 10. Histogram for BOD and Normal P-P Plot of Regression Standardized Residual are shown in graph 8 and 9. 


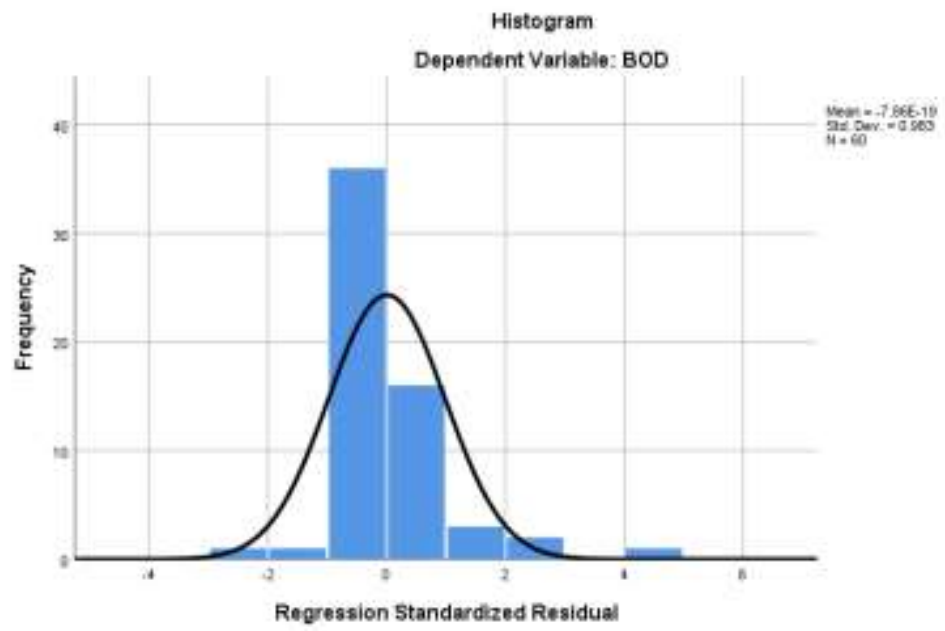

Graph 8: Histogram for BOD through SPSS



Graph 9: Normal P-P Plot of Regression Standardized Residual through SPSS

\section{CONCLUSION}

It is need of the hour to determine the status and trend of surface water for on regular basis to take decision for multicriteria like requirements of treatment of the lakes. It is beneficial for human health as well as aquatic life, need of industries, tourism agriculture. Multi-dimensional growth of Udaipur city will be possible through maintenance and improvement of the all lakes system. This study is helpful for future planning of development of the Udaipur. This study shows the comparative analysis of water quality three major lakes i.e. Fatehsagar, Pichola lake and Udaisagar lake. High values of BOD, pH, Conductivity, Total coliform, Fecal Coliform of Udaisagar lake represent that it is most polluted lake among three. According to the result of regression model of three lakes Biochemical Oxygen Demand is mainly affected by temperature and total coliform. Overall water quality has been improved in last 10 years (2010 to 2019) especially during 2016 to 2018 due to development of waste water treatment plant through agreement between the Hindustan Zinc Company and local administration. There are some results which represent high fecal and total coliform pollution in Pichola Lake due to leakage of sewage line near the lake. These continuous water analyses are required to identify the reason of pollution timely for taken action for mitigation process.

\section{REFERENCES}

1. K. C. Sharma, C. S. Chouhan, P. D. Charan, Mudita Nag. Water quality and restoration practices of lake Budha Pushkar - A threatened water body of Ajmer, Rajasthan. The Ecoscan,3 (1\&2) : 53-58, 2009.

2. Vijayakumar B. Fresh water ecosystem of India. Daya publishing house Delhi. 1999, 336.

3. Delpla, A.-V. Jung, E. Baures, M. Clement, O. Thomas. Impacts of climate change on surface water quality in relation to drinking water production. Environment International 35 (2009) 1225-1233 


\section{International Advanced Research Journal in Science, Engineering and Technology}

Vol. 8, Issue 10, October 2021

\section{DOI: 10.17148/IARJSET.2021.81030}

4. Evans CD, Monteith DT, Cooper DM. Long-term increases in surface water dissolved organic carbon: observations, possible causes and environmental impacts. Science Direct. Env Poll 2005;137:55-71.

5. Jones JG. Studies on Freshwater bacteria factor which influence the population and its activity J. Ecol. 1971; 60:59-75.

6. Sally Applebaum, Paul A. Montagna, Christine Ritter. Status and Trends of Dissolved Oxygen in Corpus Christi Bay, Texas, U.S.A. Springer Link107, pages 297-311 (2005).

7. $\quad$ L. L. Sharma and M. C. Gupta. Some aspects of water quality in a shallow pond of Udaipur, Rajasthan. Rec zool. Surv. India, 94 (2-4): 395-402, 1994

8. B. K. Das. Environmental pollution of Udaisagar lake and impact of phosphate mine, Udaipur, Rajasthan, India. Environmental Geology, Springer Link, 38, pages 244-248(1999).

9. Gheorghe Romanescu, Cristian C. Stoleriu. Seasonal Variation of Temperature, pH, and Dissolved Oxygen Concentration in Lake Rosu, Romania. Springer Link.

10. Choi K, Kim Y, Park J, Park CK, Kim M, Kim HS, Kim P. Seasonal variations of several pharmaceutical residues in surface water and sewage treatment plants of Han River. Sci Total Environ 2008;405:102-28.

11. Mathivanan, Vijayan VP, Salvi Sabhanayakam. An assessment of water quality of river cauvery at mettur, Salem district, Tamil Nadu in relation to population. Journal of Current Sciences. 2004; 5:573-578.

12. David, M.M.; Haggard, B.E. Development of regression-based models to predict fecal bacteria numbers at select sites within the Illinois River watershed, Arkansas and Oklahoma, USA. Water Air Soil Pollution, 2011, 215, 525-547.

13. Ritu Singh Rajput, Sonali Pandey and Seema Bhadauria. Status of water pollution in relation to industrialization in Rajasthan. De Gruyter, Rev Environ Health 2017; 32(3): 245-252.

14. N.C. Kankal, M.M. Indurkar, S.K. Gudadhe and S.R. Wate. Water Quality Index of Surface Water Bodies of Gujarat, India. Asian J. Exp. Sci., Vol. 26, No. 1, 2012; 39-48.

$15 . \quad$ T. Yamada, T. Inoue, h. Fukuhara, O. Nakahara, T. Izuta, R. Suda, M. Takahashi, H. Sase, A. Takahashi, H. Kobayashi, T. Ohizumi, T. Hakamata. Long-term Trends in Surface Water Quality of Five Lakes in Japan. Springer Link.

16. K.Ambiga and R. Anna Durai. Development of Water Quality Index and Regression Model for Assessment of Ground Water Quality.

17. Jones JG. Studies on freshwater bacteria: association with algae and alkaline phosphate activity J. Ecol. 1972; 60:59-75.

18. V. P. A. Weerasinghe, Kosala Handapangoda. Surface water quality analysis of an urban lake; East Beira, Colombo, Sri Lanka. Science

Direct.

19. Mishra Amarnath, Nagda Bharat. Study of Water Quality in Udaipur Region, India. Asian Journal of Water, Environment and Pollution, vol. 17, no. 1, pp. 51-57, 2020.

20. Liu Yang, Ke-Ming Ma, Jing-Zhu Zhao, Xue Bai, Qing-Hai Guo. The relationships of urbanization to surface water quality in four lakes of Hanyang, China. International Journal of Sustainable Development \& World Ecology, Volume 14, 2007 - Issue 3.

21. Karim Loucif, Souad Neffar, Taha Menasria, Mohamed Cherif Maazi, Moussa Houhamdi, Haroun Chenchouni. Physico-chemical and bacteriological quality assessment of surface water at Lake Tonga in Algeria. Science Direct.

22. WHO (2008). Standards for Drinking Water Quality, $3^{\text {rd }}$ Edition. World Health Organization. Geneva.

23. Howell JM, Coyne MS, Cornelius PL. Effect of sediment particle size and temperature on fecal bacteria mortality rates and the fecal coliform/fecal streptococci ratio. Journal of Environmental Quality. 1994; 25:1216-1220.

24. Henrici AT. Studies of fresh water bacteria: IV. Seasonal fluctuations of lake bacteria in relation to plankton production. Journal of Bacteriology, 1938; 35:129.

25. APHA (2017). Standard methods for Examination of water and waste water. American Public Health Association $23^{\text {rd }}$ Ed. APHA, New York.

26. Pushkar Lal Dangi, BK Sharma and B Uppadhyay. BOD, Total and Faecal coliforms, bacterial status of Lake Pichhola, Udaipur, Rajasthan. International Journal of Fisheries and Aquatic Studies 2017; 5(3): 176-180. 